\title{
Growth and Visual Symptoms of Nutrients Deficiency in Mangosteens (Garcinia mangostana L.)
}

\author{
Ismael de Jesus Matos Viégas ${ }^{1 *}$, Ricardo Augusto Martins Cordeiro², Gabriela Mourão de Almeida ${ }^{3}$, \\ Diocléa Almeida Seabra Silva1, Bianca Cavalcante da Silva', Ricardo Shigueru Okumura3 \\ Mário Lopes da Silva Júnior ${ }^{4}$, Sávia Poliana da Silva ${ }^{4}$, Joze Melisa Nunes de Freitas ${ }^{3}$
}

\author{
${ }^{1}$ Universidade Federal Rural da Amazônia, Capanema Campus, Capanema, Brazil \\ ${ }^{2}$ Institute Federal do Pará, Castanhal Campus, Castanhal, Brazil \\ ${ }^{3}$ Universidade Federal Rural da Amazônia, Capitão Poço Campus, Capitão Poço, Brazil \\ ${ }^{4}$ Universidade Federal Rural da Amazônia, Belém Campus, Belém, Brazil \\ Email: *ismael.viegas@ufra.edu.br
}

How to cite this paper: de Jesus Matos Viégas, I., Cordeiro, R.A.M., de Almeida, G.M., Silva, D.A.S., da Silva, B.C., Okumura, R.S., da Silva Júnior, M.L., da Silva, S.P. and de Freitas, J.M.N. (2018) Growth and Visual Symptoms of Nutrients Deficiency in Mangosteens (Garcinia mangostana L.). American Journal of Plant Sciences, 9, 1014-1028.

https://doi.org/10.4236/ajps.2018.95078

Received: February 18, 2018

Accepted: April 17, 2018

Published: April 20, 2018

Copyright (c) 2018 by authors and Scientific Research Publishing Inc. This work is licensed under the Creative Commons Attribution International License (CC BY 4.0).

http://creativecommons.org/licenses/by/4.0/ (c) (i) Open Access

\begin{abstract}
The aims of study were to evaluate growth and characterize the visual symptoms of macronutrient and micronutrient deficiencies in mangosteens. The seedlings were cultivated in nutritive solution containing all required macronutrient and micronutrients and in solutions with omission of $\mathrm{N}, \mathrm{P}, \mathrm{K}, \mathrm{Ca}$, $\mathrm{Mg}, \mathrm{S}, \mathrm{B}, \mathrm{Cu}, \mathrm{Fe}, \mathrm{Mn}$, and $\mathrm{Zn}$, using the missing element technique. The experimental design was completely randomized with five replicates and twelve treatments. Symptoms of nutrient deficiency were accompanied by photographic records and described from beginning until complete definition, in which the plants were collected. Growth was evaluated through of dry mass production and nutrient contents. Nutrients omissions resulted in morphological alterations, characteristic symptoms of nutritional deficiency, promoted the reduction in dry mass production in plant, in which the Fe was most limiting, followed by N, and S. Macronutrients and micronutrients contents, without deficiencies (complete treatment) and deficient in mangosteen leaves were respectively: $\mathrm{N}$ (16.4 and $\left.12.5 \mathrm{~g} \mathrm{~kg}^{-1}\right) ; \mathrm{P}\left(1.1\right.$ and $\left.0.2 \mathrm{~g} \mathrm{~kg}^{-1}\right) ; \mathrm{K}\left(10.2\right.$ and $\left.8.1 \mathrm{~g} \mathrm{~kg}^{-1}\right) ; \mathrm{Ca}$ (6.7 and $\left.1.9 \mathrm{~g} \mathrm{~kg}^{-1}\right) ; \mathrm{Mg}\left(1.1\right.$ and $\left.0.1 \mathrm{~g} \mathrm{~kg}^{-1}\right) ; \mathrm{S}\left(3.0\right.$ and $\left.2.2 \mathrm{~g} \mathrm{~kg}^{-1}\right) ; \mathrm{B}(20$ and 16 $\left.\mathrm{mg} \mathrm{kg}^{-1}\right)$; $\mathrm{Cu}\left(7\right.$ and $\left.3 \mathrm{mg} \mathrm{kg}^{-1}\right) ; \mathrm{Fe}\left(266\right.$ and $\left.86 \mathrm{mg} \mathrm{kg}^{-1}\right) ; \mathrm{Mn}(58$ and $17 \mathrm{mg}$ $\mathrm{kg}^{-1}$ ). The decreasing order in appearance of visual symptoms of deficiency was $\mathrm{N}>\mathrm{S}>\mathrm{K}>\mathrm{B}>\mathrm{Ca}>\mathrm{P}>\mathrm{Mg}>\mathrm{Mn}>\mathrm{Cu}>\mathrm{Zn}$.
\end{abstract}

\section{Keywords}

Mineral Nutrition, Tropical Fruit, Nutritional Deficiency, Missing Element 


\section{Introduction}

The Amazon region presents favorable edaphoclimatic conditions for development of production systems with tropical fruits, among the species of economic interest the mangosteen (Garcinia mangostana L.) has been highlighted, due to interest of national and international consumer markets. Belonging to Clusiaceae family, native to Southeast Asia, the mangosteen has been considered by many as "fruit queen" by its incomparable flavor and aroma, cultivated in tropical countries of Africa, Central America, South America and the United States. In Brazil it was introduced in Bahia State (year 1935) and later in Pará State (year 1942) [1]. In Pará state, mangosteen is concentrated in Santa Isabel do Pará, Benevides, Castanhal, Marituba, Santo Antônio do Tauá, and Tomé-Açu city, being a large part consortium with other fruit species such as açaí, cupuassu, banana, and orange [2].

The mangosteen fruit has a high pharmacological potential, the bark of fruit when sectioned develops a substance similar to resin, rich in pectin and with high combinations of polyphenols contents [3]. Fruit pericarp is one of major sources of xanthones [4], showing antioxidant [5], antibacterial, antifungal, anti-inflammatory [6], and antileukemic activity [7] [8].

The high pharmacological and economic potential of mangosteen fruit has promoted the conquest of new frontiers, providing the need for further studies in several areas that constitute the productive chain, among which those are related to nutritional aspects. Information on nutritional requirements of plants is important to know the actual demand of each nutrient, determining the correct amounts of fertilizers to be applied.

Thus, the missing element technique provides information related to nutritional disorders, excess and deficiencies, in decreased vegetative development and crop yield, detected by visual symptoms of deficiency, more pronounced in the leaves.

The development of a database with photographs and detailed descriptions of symptoms in nutritional deficiencies specific to plant species contributes to successful evaluation of technician or farmer. Although there is a description in literature of symptoms of nutrient deficiency, the expression of nutritional disorders varies interspecies and intraspecies [9], as well as symptoms of nutritional deficiency in plants can be confused with symptoms developed by biotic or abiotic stress [10].

Depending on plant species, the symptoms of nutritional deficiencies are shown with some peculiarities [11]. To use the diagnosis by visual method is necessary the reliability that problem is occurring due by deficiency or excess of nutrients, since the incidence of pests and diseases, among others, in which provides difficulty in diagnosis because it promotes similar symptoms as nutritional. In cases of nutritional disorder, the symptoms usually show on leaves of dispersion, symmetry, and gradient characteristics [12] [13].

In mangosteen culture, the studies developed do not contemplate the symptoms of macronutrients and micronutrients and description of evolution of 
symptoms. Thus, the aims of study were to evaluate the effect of omission of macronutrients and micronutrients on growth, visual symptoms of nutritional deficiencies and mineral composition in mangosteen plants.

\section{Material and Methods}

\subsection{Plant Materials}

Seeds were obtained from matrices originating from Embrapa Amazônia Oriental, Belém city, Pará State, Brazil, in which were washed for purpose of removing the pulp, and later sowed in a bed containing sand and sawdust mixture in a ratio of 3:1. Thirty days after sowing before the appearance of first two leaves, plants were transferred into black plastic bags with dimensions of $15 \mathrm{~cm}$ (width) $\times 25 \mathrm{~cm}$ (height), containing mixture of black earth, sawdust, and cattle manure in a ratio of 3:1:1, showing the following chemical characteristics: $\mathrm{pH}_{\mathrm{H}_{2} \mathrm{O}}$ 8.10; $53.00 \%$ (organic matter); $1.78 \%$ (N-total); $0.54 \%\left(\mathrm{P}_{2} \mathrm{O}_{5}\right) ; 1.07 \%\left(\mathrm{~K}_{2} \mathrm{O}\right) ; 16.10$ $(\mathrm{C} / \mathrm{N}$ ratio); $2.96 \%(\mathrm{CaO}) ; 0.48 \%(\mathrm{MgO})$; and $0.34 \%(\mathrm{~S})$.

\subsection{Experimental Design}

The experiment was conducted at Embrapa Amazônia Oriental, Belém city, Pará State, Brazil, during 200 days under greenhouse conditions with temperatures varying from $25^{\circ} \mathrm{C}$ to $30^{\circ} \mathrm{C}$. Experimental design was a completely randomized design, with four replications and twelve treatments: nutritive solution containing all required macronutrient and micronutrients and in solutions with omission of $\mathrm{N}, \mathrm{P}, \mathrm{K}, \mathrm{Ca}, \mathrm{Mg}, \mathrm{S}, \mathrm{B}, \mathrm{Cu}, \mathrm{Fe}, \mathrm{Mn}$, and $\mathrm{Zn}$, using the missing element technique, totaling 48 experimental plots. Table 1 shows the chemical composition of nutrient solution used in experiment.

\subsection{Conduct of Experiment}

At 10 months, when the plants reached approximately $20 \mathrm{~cm}$ in height, in which the roots were washed with distilled water to remove possible residues from the substrate, and then transplanted into the plastic pots with $10 \mathrm{~L}$ capacity, with a perforated base in order to facilitate the disposal and replacement of nutrient solution being used in experiment.

Plants were acclimatized for 60 days in Bolle-Jones [14] nutrient solution, used successfully in other researches with Amazonian crops under greenhouse conditions, modified and diluted to 1:10 [15]. Plants with a height of $50 \mathrm{~cm}$ were submitted to treatments with nutrient solution diluted to $1: 1$, total load with $\mathrm{pH}$ of \pm 5.5 .

Nutrient solution were provided by percolation in plastic pots, with capacity for $10 \mathrm{~L}$ and renewed at 15 days. Daily, monitoring was carried out at solution level in collection bottles, completing them for $1 \mathrm{~L}$ per plant, when necessary adding distilled water.

\subsection{Experimental Evaluations}

During the experiment were collected leaf samples and description of symptoms 
Table 1. Chemical composition of nutrient solution $\left(\mathrm{mL} \mathrm{L}^{-1}\right)$ of Bolle-Jones (1954), used in experiment.

\begin{tabular}{cccccccccc}
\hline \multirow{2}{*}{ Solution } & \multicolumn{7}{c}{ Treatments } \\
\cline { 2 - 9 } & Conc. & Complete & $-\mathrm{N}$ & $-\mathrm{P}$ & $-\mathrm{K}$ & $-\mathrm{Ca}$ & $-\mathrm{Mg}$ & $-\mathrm{S}$ & $-\mathrm{B}$ \\
\hline $\mathrm{NaH} \mathrm{O}_{4}$ & $\mathrm{M}$ & 1.0 & 1.0 & - & 1.0 & 1.0 & 1.0 & 1.0 & 1.0 \\
$\mathrm{Ca}\left(\mathrm{NO}_{3}\right)_{2} \cdot 4 \mathrm{H}_{2} \mathrm{O}$ & $\mathrm{M}$ & 2.0 & - & 2.0 & 2.0 & - & 2.0 & 2.0 & 2.0 \\
$\mathrm{KNO}_{3}$ & $\mathrm{M}$ & 1.0 & - & 1.0 & - & 1.0 & 3.0 & 1.0 & 1.0 \\
$\mathrm{~K}_{2} \mathrm{SO}_{4}$ & $\mathrm{M}$ & 2.0 & 2.0 & 2.0 & - & 2.0 & 3.0 & - & 2.0 \\
$\mathrm{MgSO}_{4}$ & $0.5 \mathrm{M}$ & 2.5 & 2.5 & 2.5 & 2.5 & 2.5 & - & - & 2.5 \\
$\left(\mathrm{NH}_{4}\right)_{2} \mathrm{SO}_{4}$ & $\mathrm{M}$ & 1.5 & - & 1.5 & 2.0 & 2.5 & 2.0 & - & 1.5 \\
$\mathrm{CaSO}_{4} \cdot 2 \mathrm{H}_{2} \mathrm{O}$ & $0.01 \mathrm{M}$ & - & 200.0 & - & - & - & - & - & - \\
$\mathrm{KH}_{2} \mathrm{PO}_{4}$ & $\mathrm{M}$ & - & 1.0 & - & - & - & 1.0 & 1.0 & - \\
$\mathrm{Mg}\left(\mathrm{NO}_{3}\right)_{2}$ & $0.5 \mathrm{M}$ & - & - & - & - & - & - & 2.5 & - \\
$\mathrm{NaNO}_{3}$ & $\mathrm{M}$ & - & - & 1.0 & - & - & - & - & - \\
Solution A* & & 1.0 & 1.0 & 1.0 & 1.0 & 1.0 & 1.0 & 1.0 & $\mathrm{a}-\mathrm{B}$ \\
Solution Fe-EDTA & & 1.0 & 1.0 & 1.0 & 1.0 & 1.0 & 1.0 & 1.0 & 1.0 \\
\hline
\end{tabular}

${ }^{*}$ Composition of solution A: $141.2 \mathrm{mg} \mathrm{de} \mathrm{H}_{3} \mathrm{BO}_{3} ; 1750.0 \mathrm{mg}$ de $\mathrm{MnSO}_{4} ; 250.0 \mathrm{mg}$ de $\mathrm{CuSO}_{4} \cdot 5 \mathrm{H}_{2} \mathrm{O} ; 43.1 \mathrm{mg}$ de $\mathrm{MoO}_{3} ; 287.0 \mathrm{mg}$ de $\mathrm{ZnSO}_{4} \cdot 7 \mathrm{H}_{2} \mathrm{O}$, per liter of solution. ${ }^{*}$ Composition of solution Fe-EDTA: $26.1 \mathrm{~g}$ de $\mathrm{Na}_{2}$-EDTA; $89.2 \mathrm{~g}$ de $\mathrm{NaOHN}$ e $24.0 \mathrm{~g}$ de $\mathrm{FeSO}_{4} \cdot 7 \mathrm{H}_{2} \mathrm{O}$, per liter of solution.

through photographs, until maximum visible manifestation of nutrient deficiency. Each plant was divided in leaves, stems, and roots and then dried in an oven with forced air circulation at $70^{\circ} \mathrm{C}$ until reaching a constant mass. After, the samples were processed in a Willey mill for further chemical analysis of macronutrients and micronutrients levels in leaves, stems, and roots, according to methodology described by Malavolta [12] .

To calculate the relative growth rate (RGR) was used the equation:

$$
\operatorname{RGR}(\%)=\left(\frac{\text { D.M.O.N. }}{\text { D.M.C.T. }}\right) \times 100
$$

D.M.O.N. = dry mass of plant with nutrition omission;

D.M.C.T. $=$ dry mass of plant in complete treatment.

\subsection{Data Analysis}

Macronutrient and micronutrient levels in leaves, stems, and roots were submitted to analysis of variance, and means of treatments with omission of nutrients were compared with complete treatment using Dunnet test, at 5\% probability, using the Assistat Software Version 7.7 [16]. From of means identified in Dunnet test were performed Figures following the methodology described by Nunes et al. [17], in which consists of standardization of means founded in Dunnet test in function of different omissions. 


\section{Results and Discussion}

\subsection{Visual Symptoms Promoted by Nitrogen Deficiency}

Visual symptoms of nitrogen deficiency manifested $18^{\text {th }}$ days after the beginning of omission. Initially, older leaves gradually lost their green color from basal area, becoming yellow-green (Figure 1), with intensity of deficiency all the leaves showed yellowed (chlorotic), distributed in limbus, petiole and foliar veins.

The absorbed nitrogen is easily distributed in plants by phloem, in form of amino acids, thus, in deficiency the $\mathrm{N}$ of old leaves is redistributed to new leaves and organs of plants [15] [18], justifying the beginning of chlorosis in old leaves. According to Carneiro et al. [19], chlorosis is associated with $\mathrm{N}$ function in plant metabolism, since it is closely linked to carbon metabolism and to photorespiratory process, metabolic processes associated with photosynthesis.

Nitrogen omission interrupted the emission of new leaves, reducing the plant height (Figure 1). Batista et al. [20] observed in Annona muricata L., that nitrogen was the first visual symptom of manifested deficiency, in which the older leaves gradually lost green color, modifying in yellow with increased deficiency. Generalized chlorosis in older leaves and reduced plant height were characteristic symptoms in Theobroma grandiflorum with nitrogen deficient [21].

\subsection{Consequences of Phosphorus Deficiency in Plant}

The older leaves deficient in phosphorus showed dark green and bright coloration compared to complete treatment (Figure 1). In plant, the phosphorus deficiency promoted a reduction in plant height and in number and size of leaves (Figure 1). The symptoms presented in mangosteen occurred because the nutrient involved in various metabolic processes in plants, such as photosynthesis, respiration, gene transfer, energy transfer, synthesis of macromolecules, and active absorption of nutrients [11]. Symptoms of phosphorus deficiency observed in mangosteen were similar to obtained by Silva and Falcão [22], and Frazão and Viégas [21] in tropical fruits (Bactris gasipaes Kunth, and Theobroma grandiflorum) in which observed reduction in plant height growth with omission of phosphorus.

\subsection{Beginning and Consequences of Symptoms of Potassium Deficiency}

The symptoms of potassium deficiency in mangosteen began with marginal chlorosis in older leaves, from the apex, expanding to central part between the veins, according to development of deficiency the leaf limb showed chlorosis, with necrosis on margins and leaf apices (Figure 1). Potassium omission in nutrient solution promoted negative effects on vegetative development of plant, observing a decrease in plant height, and number and leaf size (Figure 1).

Potassium deficient plants show paralysis in process of translocation of photoassimilates to drains, resulting in accumulation of carbohydrates in leaf tissue 
[23], as well as reduction in photosynthetic efficiency promoted by decrease of conductance of mesophyll and lower capacity of fixation of $\mathrm{CO}_{2}$ [24]. Similar symptoms of potassium deficiency manifesting chlorosis, followed by necrosis in apices and margins of old leaves, reduced in plant height were identified in $A n$ nona muricata [20] (Batista et al., 2003), and Myrciaria dubia [25].

\subsection{Symptoms of Calcium Deficiency}

Calcium deficiency symptoms promote plant abnormalities, markedly characterized by reduced plant height and younger leaves, initially chlorosis along margins, remaining green leaf limb, however with intensity of deficiency results in an increase in chlorotic ranges (Figure 1). Reduction in plant height (Figure 1) and yellowing of younger leaves promoted by calcium omission were observed by Frazão and Viégas [21] in Theobroma grandiflorum and Viégas et al. [26] in Euterpe oleracea.

Calcium in plant tissue is characterized by low mobility, with limited redistribution in phloem [9], in addition, calcium deficient plants show greater action of enzyme polygalacturonase, degrading the calcium pectates responsible for stability of membranes and cell walls [27], justifying the first symptoms to be showed on younger leaves of plant.

\subsection{Visual Symptoms Promoted by Magnesium Deficiency}

The symptoms of magnesium deficiency in mangosteen were observed in older leaves of middle part of plant, with appearance of chlorosis between the veins from apex to center, remaining at base of green leaf (Figure 1). According to Hawkesford et al. [9], symptoms of magnesium deficiency occurred initially in older leaves due to high mobility in phloem, being that chlorosis in leaves is related to nutrient function, since $\mathrm{Mg}$ constitutes the central atom of chlorophyll molecule, participates in structures of thylakoid membrane [28].

Evolution of $\mathrm{Mg}$ deficiency promoted leaf senescence, reduced plant height and reduced number and size of mangosteen leaves (Figure 1). The symptoms of magnesium deficiency, chlorosis among the veins, were observed in Annona muricata [20], Theobroma grandiflorum [21], Bactris gasipaes Kunth [22], and Euterpe oleracea [26] cultivated in Brazilian Amazon.

\subsection{Beginning and Consequences of Symptoms of Sulfur Deficiency}

Sulfur-deficient in mangosteen plants showed on new leaves symptoms of yellowish-green coloration, with a lighter shade of color compared to leaves of complete treatment (Figure 1). Symptoms of sulfur deficiency are similar to nitrogen (sulfur is involved in composition of two essential amino acids, cystine and methionine, and in protein synthesis) [28], however, sulfur has limited redistribution in phloem, thus, low translocation of nutrient from old leaves to new leaves [29]. 
Symptoms of sulfur deficiency characterized by yellowing of younger leaves were observed in fruit trees, Annona muricata [20], Theobroma grandiflorum [21], Myrciaria dubia [25], and Euterpe oleracea [26], cultivated in Brazilian Amazon.

\subsection{Symptoms of Micronutrients Deficiency in Plant}

Boron: Boron deficiency in mangosteen was characterized by showing yellowish new leaves, twisted, atrophied, small, and thick leaves (Figure 1) promoted by absence of boron in lamella medial and cell wall through pectic connections between two complexes called rhamnogalacturonan [30]. According to intensity of symptoms caused the death of apical meristem, promoting sprouts, and stem of plants showed to be thicker, with greater diameter of stem. Symptoms of boron deficiencies showing the same characteristics were described in Euterpe oleracea [26], Theobroma grandiflorum [31], and Cocos nucifera [32].

Copper: Copper deficiency initially manifested with yellowing of new leaves with pale green coloration between the veins. With increased symptoms, leaves showed deformed, narrow, with progression to central part (Figure 1). Enzymes polyphenoloxidase, ascorbate oxidase, and diamino oxidase are composed of copper, occurring in cell wall, playing a role in biosynthetic pathways of phenol, starting in quinone pathway until the formation of melanin and lignin, substances that increase the resistance to entry of pathogens. Thus, copper deficiency decreases the activity of enzymes (polyphenoloxidase, ascorbate oxidase, and diamino oxidase), promoting the accumulation of phenols and decrease in formation of lignin and melalines [33].

Iron: Iron deficiency symptoms were first to manifest, less than $15^{\text {th }}$ days after initiation of treatments, showing that mangosteen is sensitive to iron deficiency. In leaf the symptoms were characterized by chlorosis in new leaves, veins with fine reticulate and yellowish background, remaining green vein. With increased deficiency, in plant observed an increase in number of shoots, while leaf showed completely yellowish, including vein, then necrosis from apex to center of leaf (Figure 1).

Iron in plant has function of maintaining the functional and structural integrity of thylakoid membrane, as well as essential for ferredoxin and chlorophyll biosynthesis, justifying high sensitivity of chloroplasts (chlorosis) and thylakoids to iron deficiency [11]. From results obtained in present study observed a reduction in plant height and leaf area compared to complete treatment, symptoms were similar to described by Moraes et al. [34], studying nutritional limitations in mangosteen seedlings.

Manganese: The initial symptom of manganese deficiency in mangosteen was yellowing between veins with thick reticulate in newer leaves and bands of green tissue surrounding main vein. With evolution of symptoms of deficiency, leaves showed with chlorosis and smaller size. In general, manganese-deficient showed changes in chloroplasts with disarray of thylakoid cells and absence of stromal 
lamellae, since chloroplasts (site of occurrence of photosynthetic process) are organelles most sensitive to micronutrient deficiency [35].

Zinc: Small and thin leaves with chlorotic areas between veins were symptoms of zinc deficiencies observed in new leaves of mangosteen (Figure 1). Zinc has a direct influence on carbohydrate metabolism [36], as well as participates in metabolism of nitrogen, promoting accumulation of amino acids in plants deficient of zinc [37].

\subsection{Production of Dry Mass}

With exception of zinc omission (in all variables) and copper omission (RDM and LDM) (Figure 2(a) and Figure 2(c)), other nutrient omissions limited the dry mass production compared to complete treatment (Table 2). The nutrients that most limited dry mass production (Figure $2(\mathrm{e})$ ) in various parts of the plant
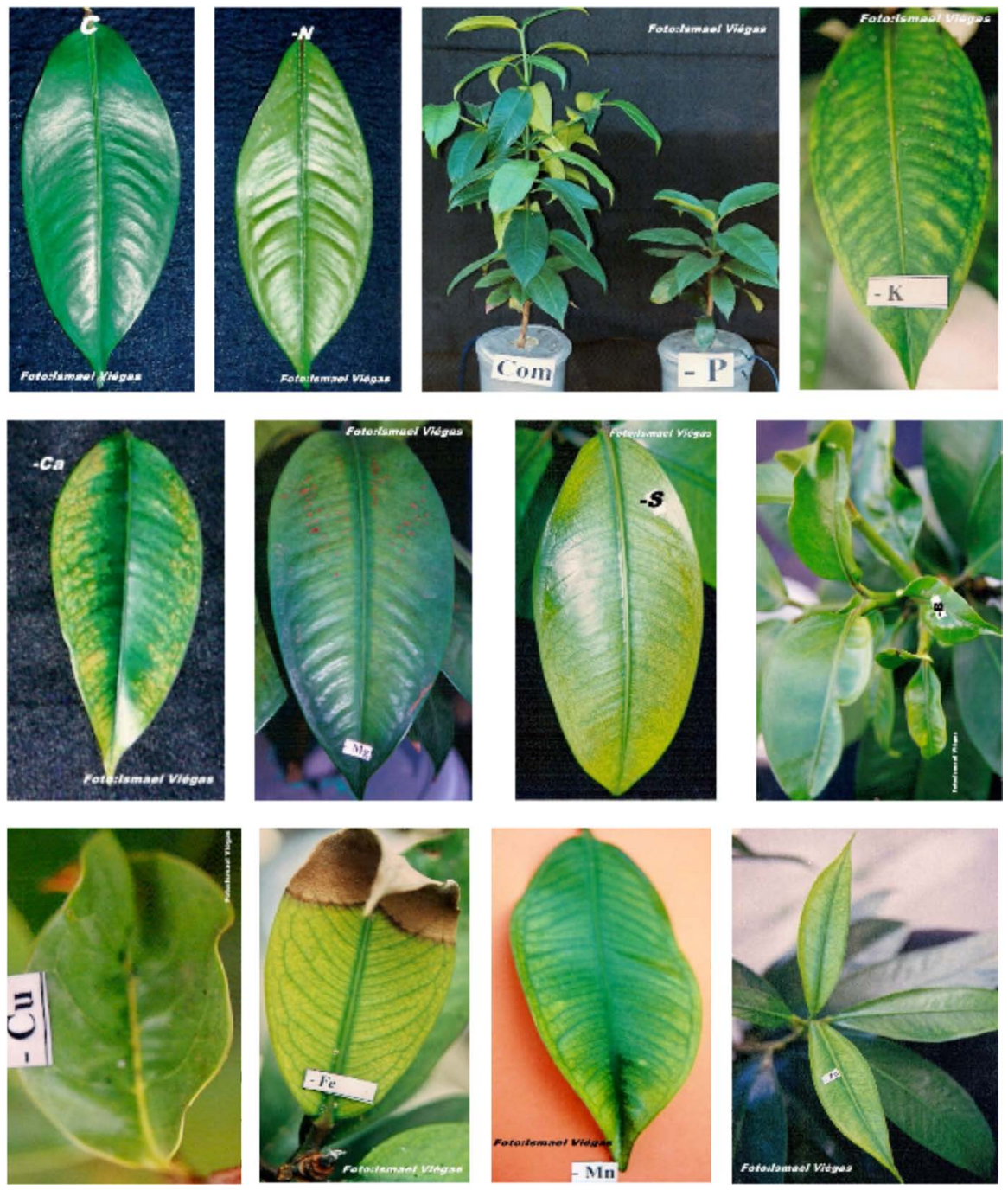

Figure 1. Mangosteen leaves with symptoms of deficiencies of nitrogen, (-N), phosphorus $(-\mathrm{P})$, potassium $(-\mathrm{K})$, calcium $(-\mathrm{Ca})$, magnesium $(-\mathrm{Mg})$, sulfur $(-\mathrm{S})$, boron $(-\mathrm{B})$, copper $(-\mathrm{Cu})$, iron $(-\mathrm{Fe})$, manganese $(-\mathrm{Mn})$, and zinc $(-\mathrm{Zn})$ compared to leaf and plant with complete treatment $(\mathrm{C})$. 



Figure 2. Graphical representation considering the average variation of leaf dry matter (a), stem (b), roots (c), aerial part (d), aerial part/root ratio (e), total (f), and relative growth rate $(\mathrm{g})$ for all omissions and complete treatment.

were iron, nitrogen, and sulfur. The reduction in total dry mass production with omission of nutrients were $94 \%(-\mathrm{Fe}), 93 \%(-\mathrm{N})$, and $87 \%(-\mathrm{S})$.

According to Marschner [11], iron is an important enzymatic activator as well as sulfur and nitrogen are nutrients constituent of formation of proteins being essential in metabolic activity, having a more structural function in plants. Iron limitation on mangosteen growth is not worrisome, because plantations of fruit tree are mostly established in Yellow Latosols, which have high levels of iron, considered as ferralitic soils. On the other hand, limitation on growth in nitrogen and sulfur should receive more attention due to limitation showed by soil.

The production of total dry mass in absolute values showed the following limiting order: $\mathrm{Fe}>\mathrm{N}>\mathrm{S}>\mathrm{K}>\mathrm{B}>\mathrm{Ca}>\mathrm{P}>\mathrm{Mg}>\mathrm{Mn}>\mathrm{Cu}>\mathrm{Zn}$. Based on 
Table 2. Leaf dry matter (LDM), stem (SDM), roots (RDM), aerial part (APDM), aerial part/root ratio $(\mathrm{AE} / \mathrm{R})$, total $(\mathrm{TDM})$ and relative growth rate (RGR) in mangosteen plants.

\begin{tabular}{cccccccc}
\hline \multirow{2}{*}{ Treatment } & LDM & SDM & RDM & APDM & AP/R & TDM & RGR \\
\cline { 2 - 8 } C & 102.24 & 92.37 & 51.59 & 194.62 & 3.79 & 246.22 & 100.00 \\
$-\mathrm{N}$ & $9.26-$ & $5.18-$ & $3.97-$ & $14.44-$ & $3.66^{\mathrm{ns}}$ & $18.42-$ & $7.48-$ \\
$-\mathrm{P}$ & $28.32-$ & $20.10-$ & $33.23-$ & $48.42-$ & $1.45-$ & $81.65-$ & $33.17-$ \\
$-\mathrm{K}$ & $15.56-$ & $14.23-$ & $16.37-$ & $29.80-$ & $1.90-$ & $46.18-$ & $18.77-$ \\
$-\mathrm{Ca}$ & $36.02-$ & $19.22-$ & $24.52-$ & $55.24-$ & $2.26-$ & $79.77-$ & $32.40-$ \\
$-\mathrm{Mg}$ & $37.90-$ & $26.78-$ & $21.24-$ & $65.18-$ & $3.09^{\text {ns }}$ & $86.42-$ & $35.12-$ \\
$-\mathrm{S}$ & $17.84-$ & $8.26-$ & $5.99-$ & $26.97-$ & $4.58^{\mathrm{ns}}$ & $32.96-$ & $13.39-$ \\
$-\mathrm{B}$ & $26.26-$ & $25.96-$ & $19.76-$ & $52.23-$ & $2.67-$ & $71.99-$ & $29.22-$ \\
$-\mathrm{Cu}$ & $100.39^{\mathrm{ns}}$ & $77.93-$ & $51.31^{\mathrm{ns}}$ & $178.33-$ & $3.48^{\mathrm{ns}}$ & $229.64-$ & $93.29-$ \\
$-\mathrm{Fe}$ & $7.62-$ & $3.67-$ & $2.77-$ & $11.30-$ & $4.12^{\mathrm{ns}}$ & $14.07-$ & $5.71-$ \\
$-\mathrm{Mn}$ & $63.53-$ & $41.41-$ & $36.98-$ & $104.94-$ & $2.86^{\text {ns }}$ & $141.93-$ & $57.64-$ \\
$-\mathrm{Zn}$ & $103.44^{\mathrm{ns}}$ & $88.68^{\mathrm{ns}}$ & $56.11^{\mathrm{ns}}$ & $192.13^{\mathrm{ns}}$ & $3.43^{\mathrm{ns}}$ & $248.24^{\mathrm{ns}}$ & $100.81^{\mathrm{ns}}$ \\
$\mathrm{DMS}$ & 5.09 & 5.86 & 5.70 & 9.77 & 0.79 & 11.98 & 4.96 \\
$\mathrm{CV} \%$ & 5.46 & 8.14 & 10.35 & 5.90 & 12.56 & 5.43 & 5.53 \\
\hline
\end{tabular}

+Significant and higher than complete treatment, by Dunnett test, at a $5 \%$ probability level; -Significant and less than complete treatment, by Dunnett test, at a $5 \%$ probability level; ${ }^{\text {ns}}$ Not significant, by Dunnett test, at a $5 \%$ probability level.

complete treatment, highest dry mass production occurred on the leaves, followed by stem and roots.

\subsection{Nutrient Level in Leaves, Stems, and Roots}

The individual omissions of $\mathrm{N}, \mathrm{P}, \mathrm{K}, \mathrm{Ca}, \mathrm{Mg}, \mathrm{S}, \mathrm{Cu}, \mathrm{Fe}$, and $\mathrm{Mn}$ reduced the leaf level of their respective nutrient compared to complete treatment. The leaf level of boron also reduced with omission of micronutrient, but not significantly compared to complete treatment. Zinc omission showed a zinc leaf level similar to complete treatment.

Macronutrient level in complete treatment were in order $\mathrm{N}>\mathrm{K}>\mathrm{Ca}>\mathrm{S}>\mathrm{P}=$ $\mathrm{Mg}$ and, in micronutrients $\mathrm{Fe}>\mathrm{Mn}>\mathrm{B}>\mathrm{Zn}>\mathrm{Cu}$. Based on leaves levels of macronutrients and micronutrients in mangosteens, following values are obtained in a first approximation: non-deficient (complete) and deficient (omission) values, respectively: $\mathrm{N}$ (16.4 and $\left.12.5 \mathrm{~g} \mathrm{~kg}^{-1}\right) ; \mathrm{P}\left(1.1\right.$ and $\left.0.2 \mathrm{~g} \mathrm{~kg}^{-1}\right) ; \mathrm{K}(10.2$ and $\left.8.1 \mathrm{~g} \mathrm{~kg}^{-1}\right) ; \mathrm{Ca}\left(6.7\right.$ and $\left.1.9 \mathrm{~g} \mathrm{~kg}^{-1}\right) ; \mathrm{Mg}\left(1.1\right.$ and $\left.0.1 \mathrm{~g} \mathrm{~kg}^{-1}\right) ; \mathrm{S}(3.0$ and $2.2 \mathrm{~g}$ $\left.\mathrm{kg}^{-1}\right)$; B (20 and $\left.16 \mathrm{mg} \mathrm{kg}^{-1}\right) ; \mathrm{Cu}\left(7\right.$ and $\left.3 \mathrm{mg} \mathrm{kg}^{-1}\right) ; \mathrm{Fe}$ (266 and $\left.86 \mathrm{mg} \mathrm{kg}^{-1}\right) ; \mathrm{Mn}$ (58 and $17 \mathrm{mg} \mathrm{kg}^{-1}$ ) (Table 3).

The individual omissions of $\mathrm{N}, \mathrm{P}, \mathrm{K}, \mathrm{Ca}, \mathrm{Mg}, \mathrm{Cu}, \mathrm{Mn}$, and Fe reduced stem level of their respective nutrient compared to complete treatment, other omissions 
Table 3. Macronutrients and micronutrients levels in leaves, stems, and roots of mangosteens.

\begin{tabular}{|c|c|c|c|c|c|c|c|c|c|c|c|}
\hline \multicolumn{12}{|c|}{ Leaves } \\
\hline & $\mathrm{N}$ & $\mathrm{P}$ & K & $\mathrm{Ca}$ & $\mathrm{Mg}$ & $S$ & B & $\mathrm{Cu}$ & $\mathrm{Fe}$ & $\mathrm{Mn}$ & $\mathrm{Zn}$ \\
\hline \multicolumn{7}{|c|}{$\mathrm{g} \mathrm{kg}^{-1}$} & \multicolumn{5}{|c|}{$\mathrm{mg} \mathrm{kg}^{-1}$} \\
\hline $\mathrm{C}$ & 16.47 & 1.15 & 10.20 & 6.67 & 1.17 & 3.05 & 20.40 & 7.08 & 266.02 & 57.97 & 12.86 \\
\hline$-\mathrm{N}$ & $12.50-$ & $1.15^{\mathrm{ns}}$ & 7.35- & $6.35^{\mathrm{ns}}$ & $1.70+$ & $2.42-$ & $116.26+$ & $8.25^{\mathrm{ns}}$ & $116.33-$ & $117.97+$ & $23.47+$ \\
\hline$-\mathrm{P}$ & $13.90-$ & $0.20-$ & $8.10-$ & $5.20-$ & $0.70-$ & $2.65^{\mathrm{ns}}$ & $33.34-$ & $6.39^{\mathrm{ns}}$ & $57.06-$ & $61.59^{\mathrm{ns}}$ & $11.02^{\mathrm{n}}$ \\
\hline$-\mathrm{K}$ & $17.12+$ & $2.42+$ & $1.70-$ & $5.97-$ & $1.90+$ & $3.37^{\mathrm{ns}}$ & $36.75-$ & $8.76^{\mathrm{ns}}$ & $60.51-$ & $80.73+$ & $21.86+$ \\
\hline$-\mathrm{Ca}$ & $17.25+$ & $0.87^{\mathrm{ns}}$ & 7.95- & $1.92-$ & $1.12^{\mathrm{ns}}$ & $3.02^{\mathrm{ns}}$ & $25.89^{\text {ns }}$ & $5.09^{\mathrm{ns}}$ & $33.09-$ & $58.63^{\mathrm{ns}}$ & $13.82+$ \\
\hline$-\mathrm{Mg}$ & $15.82-$ & $1.30^{\mathrm{ns}}$ & $9.75^{\mathrm{ns}}$ & $6.05^{\mathrm{ns}}$ & $0.15-$ & $2.40-$ & $26.91+$ & $7.42^{\mathrm{ns}}$ & $47.47-$ & $93.02+$ & $16.80+$ \\
\hline$-S$ & $14.75-$ & $0.77^{\mathrm{ns}}$ & $12.45+$ & $6.25^{\mathrm{ns}}$ & $0.65-$ & $2.17-$ & $53.80+$ & $4.38-$ & $80.78-$ & $55.94^{\mathrm{ns}}$ & $12.41^{\mathrm{n}}$ \\
\hline$-B$ & $15.57-$ & $1.20^{\mathrm{ns}}$ & $7.40-$ & $5.40-$ & $0.52-$ & $2.22-$ & $15.17^{\mathrm{ns}}$ & $6.59^{\mathrm{ns}}$ & $58.66-$ & $82.96+$ & $13.93^{\mathrm{n}}$ \\
\hline$-\mathrm{Cu}$ & $14.27^{\mathrm{ns}}$ & $1.30^{\mathrm{ns}}$ & $9.15^{\mathrm{ns}}$ & $6.00^{\text {ns }}$ & $1.02^{\mathrm{ns}}$ & $2.85^{\mathrm{ns}}$ & $17.19^{\text {ns }}$ & 3.19- & $57.34-$ & $45.86-$ & $11.04^{\mathrm{n}}$ \\
\hline$-\mathrm{Fe}$ & $22.05+$ & $2.67+$ & $12.00+$ & $9.20+$ & $0.75-$ & $3.50+$ & $118.13+$ & $9.18^{\mathrm{ns}}$ & 86.04- & $140.2-$ & $45.66+$ \\
\hline$-M n$ & $15.55-$ & $1.22^{\mathrm{ns}}$ & $8.85-$ & $6.32-$ & $1.02^{\mathrm{ns}}$ & $2.90^{\mathrm{ns}}$ & $21.70^{\text {ns }}$ & $6.78^{\mathrm{ns}}$ & $74.88-$ & $17.37-$ & $14.46^{\mathrm{n}}$ \\
\hline$-\mathrm{Zn}$ & $14.07^{\mathrm{ns}}$ & $1.27^{\mathrm{ns}}$ & $7.60-$ & $5.72-$ & $1.00^{\mathrm{ns}}$ & $2.90^{\mathrm{ns}}$ & $18.24^{\mathrm{ns}}$ & $4.63-$ & $59.76-$ & $46.29^{\mathrm{ns}}$ & $12.26^{\mathrm{n}}$ \\
\hline DMS & 1.89 & 0.67 & 1.51 & 0.68 & 0.24 & 0.41 & 6.27 & 2.24 & 26.56 & 11.97 & 2.89 \\
\hline CV\% & 7.13 & 25.35 & 8.67 & 5.63 & 12.15 & 7.29 & 7.32 & 16.97 & 15.65 & 8.20 & 8.11 \\
\hline \multicolumn{12}{|c|}{ Stems } \\
\hline $\mathrm{C}$ & 11.47 & 1.60 & 11.30 & 3.50 & 0.32 & 1.95 & 15.51 & 8.30 & 18.01 & 13.32 & 11.16 \\
\hline$-\mathrm{N}$ & $8.30-$ & $1.52^{\mathrm{ns}}$ & $4.60-$ & $6.62+$ & $1.10+$ & $1.95^{\mathrm{ns}}$ & $34,54+$ & $12.89+$ & $64.77+$ & $12.56^{\mathrm{ns}}$ & $20.89+$ \\
\hline$-P$ & $8.57-$ & $0.20-$ & $4.60-$ & $6.8+$ & $0.65+$ & $2.42+$ & $22.79+$ & $7.05^{\mathrm{ns}}$ & $40.67+$ & $15.51^{\mathrm{ns}}$ & $15.05+$ \\
\hline$-\mathrm{K}$ & $19.12+$ & $3.62+$ & $1.75-$ & $5.92+$ & $1.37+$ & $3.92+$ & $20.76+$ & $16.03+$ & $60.49+$ & $21.17+$ & $25.02+$ \\
\hline$-\mathrm{Ca}$ & $17.95+$ & $2.37+$ & $6.60-$ & $1.05-$ & $0.77+$ & $3.35+$ & $15.18^{\text {ns }}$ & $8.57^{\mathrm{ns}}$ & $57.49+$ & $25.96+$ & $19.59+$ \\
\hline$-\mathrm{Mg}$ & $15.30+$ & $2.17+$ & $6.60-$ & $5.57+$ & $0.10-$ & $2.95+$ & $15.33^{\mathrm{ns}}$ & $9.24^{\mathrm{ns}}$ & $35.84+$ & $22.96+$ & $20.85+$ \\
\hline$-S$ & $11.75^{\text {ns }}$ & $1.47^{\mathrm{ns}}$ & 7.20- & $7.42+$ & $0.80+$ & $1.62^{\mathrm{ns}}$ & $44.21+$ & $8.32^{\mathrm{ns}}$ & $58.53+$ & 7.50- & $15.05+$ \\
\hline$-B$ & $16.85+$ & $1.37^{\mathrm{ns}}$ & 7.05- & $5.40+$ & $0.67+$ & $3.17+$ & $13.07^{\mathrm{ns}}$ & $16.49+$ & $44.64+$ & $28.56+$ & $21.45+$ \\
\hline$-\mathrm{Cu}$ & $11.22^{\mathrm{ns}}$ & $1.57^{\mathrm{ns}}$ & $10.65^{\mathrm{ns}}$ & $3.65^{\mathrm{ns}}$ & $0.35^{\mathrm{ns}}$ & $1.75^{\mathrm{ns}}$ & $15.34^{\mathrm{ns}}$ & $5.18-$ & $16.56^{\mathrm{ns}}$ & $11.80^{\mathrm{ns}}$ & $9.412^{\mathrm{n}}$ \\
\hline$-\mathrm{Fe}$ & $15.72+$ & $1.72^{\mathrm{ns}}$ & $11.10^{\text {ns }}$ & $8.15+$ & $0.67+$ & $3.47+$ & $35.68+$ & $15.91+$ & $44.99+$ & $45.01+$ & $47.23+$ \\
\hline$-\mathrm{Mn}$ & $10.80^{\mathrm{ns}}$ & $1.40^{\mathrm{ns}}$ & 7.10- & $3.62^{\mathrm{ns}}$ & $0.37^{\mathrm{ns}}$ & $2.32+$ & $21.29+$ & $12.27+$ & $28.14+$ & $2.40-$ & $13.17^{\mathrm{n}}$ \\
\hline$-\mathrm{Zn}$ & 9.37- & $1.42^{\mathrm{ns}}$ & 8.60- & $3.57^{\text {ns }}$ & $0.30^{\mathrm{ns}}$ & $1.72-$ & $15.00^{\text {ns }}$ & $8.07^{\mathrm{ns}}$ & $17.13^{\text {ns }}$ & $10.56^{\mathrm{ns}}$ & $8.43^{\text {ns }}$ \\
\hline DMS & 1.72 & 0.26 & 2.09 & 0.69 & 0.12 & 0.33 & 3.00 & 2.73 & 4.82 & 2.96 & 3.85 \\
\hline CV\% & 6.46 & 7.49 & 14.13 & 6.68 & 9.43 & 6.47 & 6.58 & 12.53 & 5.82 & 8.03 & 9.98 \\
\hline \multicolumn{12}{|c|}{ Roots } \\
\hline $\mathrm{C}$ & 13.12 & 6.35 & 11.85 & $3.75^{\mathrm{ns}}$ & 0.77 & 3.22 & 16.03 & 28.55 & 1516.12 & 17.79 & 64.88 \\
\hline$-\mathrm{N}$ & $9.00-$ & $3.70-$ & $9.90^{\mathrm{ns}}$ & $4.50+$ & $0.72^{\mathrm{ns}}$ & $1.52-$ & $117.34+$ & $24.91^{\mathrm{ns}}$ & 416.72- & $21.52^{\mathrm{ns}}$ & $68.37^{\mathrm{n}}$ \\
\hline$-\mathrm{P}$ & $14.30^{\mathrm{ns}}$ & $0.30-$ & $12.60^{\mathrm{ns}}$ & $5.67+$ & $0.72^{\mathrm{ns}}$ & $3.47^{\mathrm{ns}}$ & $26.29+$ & $21.89-$ & $856.87-$ & $16.77^{\mathrm{ns}}$ & $40.63-$ \\
\hline$-K$ & $16.47+$ & $5.07-$ & $2.25-$ & $3.10-$ & $1.42+$ & $2.40-$ & $26.69+$ & $22.11-$ & $1394.43^{\mathrm{ns}}$ & $21.59^{\mathrm{ns}}$ & $79.67+$ \\
\hline
\end{tabular}




\section{Continued}

\begin{tabular}{cccccccccccc}
\hline$-\mathrm{Ca}$ & $17.15+$ & $4.37-$ & $8.55+$ & $0.37-$ & $0.80^{\text {ns }}$ & $2.45-$ & $20.77^{\text {ns }}$ & $17.25-$ & $800.24-$ & $32.04+$ & $45.82-$ \\
$-\mathrm{Mg}$ & $14.12^{\text {ns }}$ & $5.15-$ & $12.75^{\text {ns }}$ & $4.15^{\text {ns }}$ & $0.10-$ & $2.20-$ & $24.90^{\text {ns }}$ & $16.34-$ & $1173.93-$ & $26.25+$ & $90.45+$ \\
$-\mathrm{S}$ & $10.67-$ & $4.37-$ & $11.85^{\text {ns }}$ & $4.35+$ & $0.77^{\text {ns }}$ & $1.32-$ & $105.09+$ & $15.99-$ & $388.49-$ & $26.01+$ & $60.27^{\text {ns }}$ \\
$-B$ & $13.40^{\text {ns }}$ & $4.42-$ & $11.85^{\text {ns }}$ & $4.55+$ & $0.77^{\text {ns }}$ & $2.40-$ & $13.40^{\text {ns }}$ & $21.31-$ & $657.49-$ & $26.13+$ & $96.02+$ \\
$-\mathrm{Cu}$ & $11.47^{\text {ns }}$ & $6.85^{\text {ns }}$ & $18.00+$ & $3.35^{\text {ns }}$ & $0.75^{\text {ns }}$ & $2.92^{\text {ns }}$ & $10.30^{\text {ns }}$ & $24.68^{\text {ns }}$ & $1347.56^{\text {ns }}$ & $18.57^{\text {ns }}$ & $66.71^{\text {ns }}$ \\
$-\mathrm{Fe}$ & $14.85^{\text {ns }}$ & $7.32-$ & $11.85^{\text {ns }}$ & $4.55+$ & $0.75^{\text {ns }}$ & $2.60-$ & $105.03+$ & $36.99+$ & $252.75-$ & $34.58+$ & $92.70+$ \\
$-\mathrm{Mn}$ & $10.70-$ & $4.87-$ & $13.05^{\text {ns }}$ & $3.75^{\text {ns }}$ & $0.55^{-}-2.35-$ & $17.03^{\text {ns }}$ & $18.89-$ & $815.06-$ & $6.95-$ & $55.30^{\text {ns }}$ \\
- Zn & $11.32^{\text {ns }}$ & $5.55-$ & $15.75+$ & $3.40-$ & $0.85^{\text {ns }}$ & $2.75^{\text {ns }}$ & $14.32^{\text {ns }}$ & $32.25^{\text {ns }}$ & $1326.31^{\text {ns }}$ & $18.26^{\text {ns }}$ & $70.85^{\text {ns }}$ \\
DMS & 1.89 & 0.60 & 2.30 & 0.57 & 0.14 & 0.50 & 9.57 & 4.90 & 221.63 & 4.08 & 10.60 \\
CV\% & 7.13 & 6.09 & 9.67 & 7.37 & 9.56 & 9.98 & 11.32 & 10.25 & 11.90 & 9.01 & 7.50
\end{tabular}

+Significant and higher than complete treatment, by Dunnett test, at a $5 \%$ probability level; -Significant

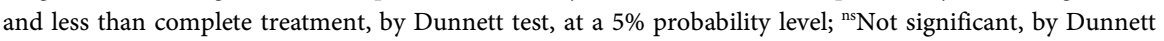
test, at a $5 \%$ probability level.

did not differ. The decreasing order of macronutrient stem level of complete treatment were: $\mathrm{N}>\mathrm{K}>\mathrm{Ca}>\mathrm{S}>\mathrm{P}>\mathrm{Mg}$ and, in micronutrients $\mathrm{Fe}>\mathrm{B}>\mathrm{Mn}>$ $\mathrm{Zn}>\mathrm{Cu}$. Macronutrient and micronutrient levels without deficiency (complete treatment) and deficiency (omissions) were respectively: $\mathrm{N}\left(11.4\right.$ and $\left.8.3 \mathrm{~g} \mathrm{~kg}^{-1}\right)$; $\mathrm{P}\left(1.6\right.$ and $\left.0.2 \mathrm{~g} \mathrm{~kg}^{-1}\right) ; \mathrm{K}\left(11.3\right.$ and $\left.1.7 \mathrm{~g} \mathrm{~kg}^{-1}\right) ; \mathrm{Ca}\left(3.5\right.$ and $\left.1.0 \mathrm{~g} \mathrm{~kg}^{-1}\right) ; \mathrm{Mg}(0.3$ and $\left.0.1 \mathrm{~g} \mathrm{~kg}^{-1}\right) ; \mathrm{S}\left(1.9\right.$ and $\left.1.6 \mathrm{~g} \mathrm{~kg}^{-1}\right) ; \mathrm{B}\left(15.5\right.$ and $\left.13.0 \mathrm{mg} \mathrm{kg}^{-1}\right) ; \mathrm{Cu}(8.3$ and 5.1 $\left.\mathrm{mg} \mathrm{kg}{ }^{-1}\right) ; \mathrm{Mn}\left(13.3\right.$ and $\left.2.4 \mathrm{mg} \mathrm{kg}^{-1}\right) ; \mathrm{Zn}\left(11.1\right.$ and $\left.8.4 \mathrm{mg} \mathrm{kg}^{-1}\right)$.

Regarding root content, omissions of all macronutrients and, Fe and Mn micronutrients reduced their respective levels, other omissions did not differ compared to complete treatment. The decreasing order of root level in macronutrients were $\mathrm{N}>\mathrm{K}>\mathrm{P}>\mathrm{Ca}>\mathrm{S}>\mathrm{Mg}$ and, in micronutrients $\mathrm{Fe}>\mathrm{Zn}>\mathrm{Cu}>$ $\mathrm{Mn}>\mathrm{B}$. Macronutrient and micronutrient levels without deficiency (complete treatment) and deficiency (omissions) were respectively: $\mathrm{N}$ (13.1 and $\left.9.0 \mathrm{~g} \mathrm{~kg}^{-1}\right)$; $\mathrm{P}\left(6.3\right.$ and $\left.0.3 \mathrm{~g} \mathrm{~kg}^{-1}\right) ; \mathrm{K}\left(11.8\right.$ and $\left.2.2 \mathrm{~g} \mathrm{~kg}^{-1}\right) ; \mathrm{Ca}\left(3.7\right.$ and $\left.0.3 \mathrm{~g} \mathrm{~kg}^{-1}\right) ; \mathrm{Mg}(0.7$ and $\left.0.1 \mathrm{~g} \mathrm{~kg}^{-1}\right) ; \mathrm{S}\left(3.2\right.$ and $\left.1.3 \mathrm{~g} \mathrm{~kg}^{-1}\right) ; \mathrm{B}\left(16.0\right.$ and $\left.13.4 \mathrm{mg} \mathrm{kg}^{-1}\right) ; \mathrm{Cu}(28.5$ and $\left.24.6 \mathrm{mg} \mathrm{kg}^{-1}\right)$; Fe (1516.0 and $\left.252.7 \mathrm{mg} \mathrm{kg}^{-1}\right)$; $\mathrm{Mn}\left(17.7\right.$ and $\left.6.9 \mathrm{mg} \mathrm{kg}^{-1}\right)$.

From results obtained in complete treatment, extracting the parts of plant observed that highest $\mathrm{N}, \mathrm{Ca}, \mathrm{Mg}, \mathrm{B}, \mathrm{Mn}$, and $\mathrm{Zn}$ levels were obtained in leaves, while of $\mathrm{P}, \mathrm{K}, \mathrm{S}, \mathrm{Cu}, \mathrm{Fe}$, and $\mathrm{Zn}$ in roots. Lowest levels of macronutrients and micronutrients were observed in stem because it is a nutrient transporting organ.

\section{Conclusion}

Mangosteen is sensitive to iron deficiency, being first nutrient to manifest the visual symptoms of deficiencies. Individual omissions of macronutrients and micronutrients in nutrient solution promote the occurrence of visual symptoms of nutritional deficiency.

Production of total dry mass is affected by nutrient omissions, with iron being 
most limiting, followed by $\mathrm{N}>\mathrm{S}>\mathrm{K}>\mathrm{B}>\mathrm{Ca}>\mathrm{P}>\mathrm{Mg}>\mathrm{Mn}>\mathrm{Cu}>\mathrm{Zn}$.

The individual omissions of $\mathrm{N}, \mathrm{P}, \mathrm{K}, \mathrm{Ca}, \mathrm{Mg}, \mathrm{S}, \mathrm{B}, \mathrm{Cu}, \mathrm{Fe}$, and $\mathrm{Mn}$ result in a reduction in leaf level of respective nutrient.

\section{Acknowledgements}

The authors are grateful to Universidade Federal Rural da Amazônia (UFRA) for the collaborations of researchers and funding institution: National Council for Scientific and Technological Development (CNPq). For Empresa Brasileira de Pesquisa Agropecuária (EMBRAPA Amazônia Oriental) and Instituto Federal de Educação, Ciência e Tecnologia do Pará (IFPA) for assistance in field work and all structural support.

\section{References}

[1] Carvalho, J.E.U. (2014) Mangosteen: Botanic, Propagation, Planting and Utilization. Revista Brasileira de Fruticultura, 36, 148-155. https://doi.org/10.1590/0100-2945-454/13

[2] Sacramento, C.K., Coelho Júnior, E., Carvalho, J.E.U., Müller, C.H. and Nascimento, W.M.O. (2007) Growing Mangosteen in Brazil. Revista Brasileira de Fruticultura, 29, 195-203. https://doi.org/10.1590/S0100-29452007000100042

[3] Ji, X., Avula, B. and Khan, I.A. (2007) Quantitative and Qualitative Determination of Six Xanthones in Garcinia mangostana L. by LC-PDA and LC-ESI-MS. Journal of Pharmaceutical and Biomedical Analysis, 43, 1270-1276. https://doi.org/10.1016/j.jpba.2006.10.018

[4] Naczk, M. and Shahidi, F. (2006) Phenolics in Cereals, Fruits and Vegetables: Occurrence, Extraction and Analysis. Journal of Pharmaceutical and Biomedical Analysis, 41, 1523-1542. https://doi.org/10.1016/j.jpba.2006.04.002

[5] Leontowicz, M., Leontowicz, H., Drzewiecki, J., Jastrzebski, Z., Haruenkit, R., Poovarodom, S., Park, Y.S., Jung, S.T., Kang, S.G., Trakhtenberg, S. and Gorinstein, S. (2007) Two Exotic Fruits Positively Affect Rat's Plasma Composition. Food Chemistry, 102, 192-200. https://doi.org/10.1016/j.foodchem.2006.05.046

[6] Ho, C.K., Huang, Y.L. and Chen, C.C. (2002) Garcinone E, a Xanthone Derivative, Has Potent Cytotoxic Effect against Hepatocellular Carcinoma Cell Lines. Planta Med, 68, 975-979. https://doi.org/10.1055/s-2002-35668

[7] Matsumoto, K., Akao, Y., Kobayashi, E., Ohguchi, K., Ito, T., Tanaka, T., Iinuma, M. and Nozawa, Y. (2003) Induction of Apoptosis by Xanthones from Mangosteen in Human Leukemia Cell Lines. Journal of Natural Products, 66, 1124-1127. https://doi.org/10.1021/np020546u

[8] Chiang, L.C., Cheng, H.Y., Liu, M.C., Chiang, W. and Lin, C.C. (2004) In vitro Evaluation of Antileukemic Activity of 17 Commonly Used Fruits and Vegetables in Taiwan. LWT-Food Science and Technology, 37, 539-544. https://doi.org/10.1016/j.lwt.2003.12.003

[9] Hawkesford, M., Horst, W., Klchey, T., Lambers, H., Schjoerring, J., Moller, I.S. and White, P. (2012) Functions of Macronutrients In: Marschner, P., Eds., Mineral Nutrition of Higher Plants, Academic Press, London, 135-189. https://doi.org/10.1016/B978-0-12-384905-2.00006-6

[10] Wiwart, M., Fordónski, G., Zur-Golazewska, K. and Suchowilska, E. (2009) Early Diagnostics of Macronutrient Deficiencies in Three Legume Species by Color Image 
Analysis. Computers and Electronics in Agriculture, 65, 125-132. https://doi.org/10.1016/j.compag.2008.08.003

[11] Marschner, H. (2012) Mineral Nutrition of Higher Plants. 3th Edition, Elsevier, London, $643 \mathrm{p}$

[12] Malavolta, E. (2006) Manual de nutrição mineral de plantas. Agronômica Ceres, Piracicaba, $631 \mathrm{p}$.

[13] Prado, R.M. (2008) Nutrição de plantas. 1th Edition, Editora UNESP, São Paulo, $407 \mathrm{p}$.

[14] Bolle-Jones, E.W. (1954) Cooper Its Effects on the Growth of Rubber Plant (Hevea brasiliensis). Plant and Soil, 10, 150-178.

[15] Viégas, I.J.M., Silva, R.N.P., Silva, D.A.S., Oliveira Neto, C.F., Conceição, H.E.O., Mascarenhas, G.S., Okumura, R.S., Monfort, L.E.F. and Silva, R.T.L. (2014) Mineral Composition and Visual Symptoms of Nutrients Deficiencies in Curauá Plants (Ananas comosus var. erectifolius). Australian Journal of Crop Science, 8, 747-753.

[16] Silva, F.A.S. and Azevedo, C.A.V. (2016) The Assistat Software Version 7.7 and Its Use in the Analysis of Experimental Data. African Journal of Agricultural Research, 11, 3733-3740. https://doi.org/10.5897/AJAR2016.11522

[17] Nunes, J.A.R., Ramalho, M.A.P. and Ferreira, D.F. (2005) Graphical Method in Studies of Adaptability and Stability of Cultivars. Annual Report of the Bean Improvement Cooperative, 48, 182-183.

[18] Pallardy, S.G. (2008) Physiology of Woody Plants. 3th Edition, Academic Press, San Diego, $454 \mathrm{p}$.

[19] Carneiro, M.M.L.C., Gomes, M.P., Santos, H.R.B., Reis, M.V., Mendonça, A.M.C. and Oliveira, L.E.M. (2015) Photorespiration and Antioxidant Metabolism in Young Rubber Plants Grown under Different Nitrogen Sources $\left(\mathrm{NO}_{3}{ }^{-}\right.$and $\left.\mathrm{NH}_{4}{ }^{+}\right)$. Revista Brasileira de Ciências Agrárias, 10, 66-73. https://doi.org/10.5039/agraria.v10i1a4941

[20] Batista, M.M.F., Viégas, I.J.M., Frazão, D.A.C., Thomaz, M.A.A. and Silva, R.C.L. (2003) Effect of Macronutrient Omission in Growth, Symptoms of Nutritional Deficiency and Mineral Composition in Soursop Plants (Annona muricata). Revista Brasileira de Fruticultura, 25, 315-318. https://doi.org/10.1590/S0100-29452003000200033

[21] Frazão, D.A.C. and Viégas, I.J.M. (2006) Cupuaçuzeiro: Nutrição, calagem e adubação. Embrapa Amazônia Oriental, Belém, 6 p.

[22] Silva, J.R.A. and Falcão, N.P.S. (2002) Characterization of Symptoms of Nutritional Deficiencies in Peach Palm Cultivated in Nutrient Solution. Acta Amazonica, 32, 529-539.

[23] Zhao, D., Oosterhuis, D.M. and Bernarz, C.W. (2001) Influence of Potassium on Photosynthesis, Chlorophyll Content, and Chloroplast Ultrastructure of Cotton Plants. Photosynthetica, 39, 103-109. https://doi.org/10.1023/A:1012404204910

[24] Jin, S.H., Huang, J.Q., Li, X.Q., Zheng, B.S., Wu, J.S., Wang, Z.J., Liu, G.H. and Chen, M. (2011) Effects of Potassium Supply on Limitations of Photosynthesis by Mesophyll Diffusion Conductance in Carya cathayensis. Tree Physiology, 31, 1142-1151. https://doi.org/10.1093/treephys/tpr095

[25] Viégas, I.J.M., Thomas, M.A., Silva, J.F., Conceição, H.E.O. and Naif, A.P.M. (2004) Effect of Omission of Macronutrient and Boron on Growth, on Symptoms of Nutritional Deficiency and Mineral Composition in Camucamuzeiro Plants (Myrciaria dubia). Revista Brasileira de Fruticultura, 26, 315-319. 
https://doi.org/10.1590/S0100-29452004000200032

[26] Viégas, I.J.M., Gonçalves, A.A.S., Frazão, D.A.C. and Conceição, H.E.O. (2008) Effects of the Omissions of Macronutrients and Boron in the Symptomatology, Growth and Production of Dry Mass in Acai Palm. Revista de Ciências Agrárias, 50, 129-141.

[27] Wehr, J.B., Menzies, N.W. and Blamey, F.P.C. (2004) Inhibition of Cell-Wall Autolysis and Pectin Degradation by Cations. Plant Physiology and Biochemistry, 42, 485-492. https://doi.org/10.1016/j.plaphy.2004.05.006

[28] Taiz, L. and Zeiger, E. (2013) Fisiologia Vegetal. 5th Edition, Artmed, Porto Alegre, 918 p.

[29] Raij, B. (2011) Fertilidade Do solo e manejo de nutrientes. International Plant Nutrition Institute, Piracicaba, $420 \mathrm{p}$.

[30] Matoh, T., Kawaguchi, S. and Kobayashi, M. (1996) Ubiquity of a Borate-Rhamnogalacturonan II Complex in the Cell Walls of Higher Plants. Plant Cell Physiology, 37, 636-640. https://doi.org/10.1093/oxfordjournals.pcp.a028992

[31] Salvador, J.O., Muraoka, T., Rossetto, R. and Ribeiro, G.A. (1994) Symptoms of Mineral Deficiencies in Cupuassu Plants (Theobroma grandiflorum) Grown in Nutrient Solution. Scientia Agricola, 51, 407-414. https://doi.org/10.1590/S0103-90161994000300005

[32] Sobral, L.F. (1998) Nutrição e adubação do coqueiro. A cultura do coqueiro no Brasil, 2, 129-157.

[33] Kirkby, E.A. and Römheld, V. (2007) Micronutrientes na fisiologia de plantas: Funções, absorção e mobilidade. Informações Agronômicas, 118, 1-24.

[34] Moraes, L.A.C., Garcia, T.B. and Moreira, A. (2006) Nutritional Limitations of Mangosteen Seedlings. Pesquisa Agropecuária Brasileira, 41, 1205-1208. https://doi.org/10.1590/S0100-204X2006000700019

[35] Meharg, A. (2011) Trace Elements in Soils and Plants. Experimental Agriculture, 47, 739-739. https://doi.org/10.1017/S0014479711000743

[36] Romheld, V. and Marschner, H. (1991) Function of Micronutrients in Plants. In: Mortvedt, J.J., Cox, F.R., Shuman, L.M. and Welch, R.M., Eds., Micronutrients in Agriculture, SSSA, Madison, 297-328.

[37] Mengel, K. and Kirkby, E.A. (1987) Principles of Plant Nutrition. International Potash Institute, Bern, 687 p. 